\title{
Genetic Variability Studies in Gladiolus (Gladiolus grandiflora L.)
}

\author{
Ishwarraddy*, K. Kandpal, A. Hugar, G. Ramesh and A. Amaregouda \\ Department of Horticulture, College of Agriculture, University of Agricultural Sciences, \\ Raichur-584102, Karnataka, India \\ *Corresponding author
}

\section{A B S T R A C T}

\begin{tabular}{|l|}
\hline K e y w o r d s \\
$\begin{array}{l}\text { Gladiolus, Phenotypic } \\
\text { coefficients of } \\
\text { variation (PCV), } \\
\text { Genotypic coefficients } \\
\text { of variation (GCV), } \\
\text { Heritability, Genetic } \\
\text { advance as percentage } \\
\text { of mean (GAM) }\end{array}$ \\
\hline Article Info \\
\hline $\begin{array}{l}\text { Accepted: } \\
18 \text { October } 2018 \\
\text { Available Online: } \\
\text { 10 November } 2018\end{array}$ \\
\hline
\end{tabular}

\section{Keywords}

Gladiolus, Phenotypic

coefficients of

Genotypic coefficients

of variation (GCV),

ritability, Genetic

of mean (GAM)

10 November 2018

\begin{abstract}
A study was conducted on genetic variability, heritability and genetic advance among various characters influencing the flower yield of twelve different genotypes of Gladiolus. The field experiment was carried out in Randomized Block Design during rabi season of 2017-18 under semi-arid climatic condition at Experimental block of Department of Horticulture, College of Agriculture, University of Agricultural Sciences, Raichur. The data was observed from five randomly selected competitive plants from each replication for eighteen quantitative traits. The analysis of variance revealed significance differences among the different genotypes. The phenotypic coefficient of variation (PCV) was higher than genotypic coefficient of variation (GCV) for all characters indicating the influence of environment on these characters. High phenotypic and genotypic coefficients of variation was observed for weight of cormels, number of corms produced, number of florets, day to $50 \%$ flowering and number of leaves at maturity. The estimates of heritability varied from 21.25 to $91.75 \%$ for different characters under study. It was found high for all the traits except number of corms produced and leaf width at maturity. High heritability estimates coupled with high genetic advance over mean was observed for all the traits except leaf width at maturity, plant height at maturity and number of days for lowest floret to open.
\end{abstract}

\section{Introduction}

Gladiolus a native of South Africa, belonging to the family Iridaceae, is one of the most popular ornamental bulbous plants grown commercially for its fascinating flowers in many parts of the world. It is popularly called as "Queen of bulbous" flowers. The common name of gladiolus is 'sword lily' because of its sword shaped foliage. In Europe it is also known as 'corn flag' because Gladiolus illyricus a wild species is found growing as weed in the corn fields.
Gladiolus is a herbaceous plant that sprouts from axillary buds of the underground corm which is a vertical compressed stem covered with dried leaf bases. The leaves of the plant are two, which grow in opposite directions and may be 15 to $120 \mathrm{~cm}$ long and 3 to $5 \mathrm{~cm}$ wide. Its inflorescence is a spike, bearing large number of florets arranged alternately on the axis in opposite direction and opening one by one in acropetal manner.

The genus Gladiolus includes about 180 species with more than 10,000 cultivars of 
which about 20 are grown commercially for cut flower purpose and many others are used as seasonal flowering plants in gardens and exhibitions. It occupies fifth place in the International floriculture trade and 4th position in bulbous flower trade (Kumar et al., 2007).

Gladiolus is very rich in its varietal wealth and exhibits enormous variability (Kumar and Yadav, 2005). The main objective of gladiolus growers is to find out the suitable variety for a particular region to produce best quality spikes, corms and cormels to meet the demand.

\section{Materials and Methods}

The experiment was carried out in Randomized Block Design with three replications in the Experimental block of Department of Horticulture, College of Agriculture, UAS, Raichur during the year of 2017-18. Twenty seven different varieties viz., Peter Pears, Careless, Red Beauty, Aldebaran, Punjab Beauty, White Prosperity, Pacific, Candyman, G. acidanthera, Agni, Nova Lux, Arka Amar, Arka Arti, Arka Darshan, Arka Poonam, Arka Gold, Arka Ayush, Pusa Vidhushi, Pusa Kiran, Urmi, Pusa Srijan, Green Willow, The Berton, Melody, Little Fawn, Dhanvantri and Hunting Song were used for the study. The entire experimental land was divided into subplots measuring 1.0 $\mathrm{m} \times 1.0 \mathrm{~m}$ and there were totally 81 plots. Bavistin (3g/litre) treated corms were planted on the ridges to a depth of 6-7 $\mathrm{cm}$ by adopting a spacing of $30 \times 20 \mathrm{~cm}$. Five randomly selected competitive plants from each replication were used for recording eighteen quantitative traits.

The observations were recorded on quantitative characters selected for genetic variability studies such as plant height at maturity $(\mathrm{cm})$, number of leaves at maturity $(\mathrm{cm})$, leaf length at maturity $(\mathrm{cm})$, leaf width at maturity $(\mathrm{cm})$, number of days for spike emergence, number of days for lowest floret to show colour, number of days for lowest floret to open, spike length $(\mathrm{cm})$, rachis length $(\mathrm{cm})$, spike girth $(\mathrm{cm})$, number of florets, number of open florets, days to $50 \%$ of flowering, number of corms produced, weight of corms $(\mathrm{g})$, number of cormels produced $(\mathrm{g})$, weight of cormels $(\mathrm{g})$, and spike per plant.

\section{Genetic variability, heritability and genetic advance}

Genetic variability is the basis for all crop improvement programmes. Higher the amount of variability in the population, greater is the scope for its improvement by selection. The importance of genetic variability was perceived by Vavilov (1951) for the first time and advocated that wide range of variability provides better scope for selecting a desirable genotype. Knowledge of heritability for different traits seems to be essential for any crop improvement programme because the heritable component is the consequence of genotype and is inherited from generation to generation. Wright (1921) reported that heritability comprised of additive and nonadditive components and it is the former which respond to selection.

The different genetic parameters was evaluated for assess the genetic variability among the various genotypes, by adopting following formulae.

\section{Estimation of variance component}

Genotypic and phenotypic components of variance were estimated with the help of following formulae.

MSS (treatment) - MSS (error)
Genotypic variance $\left(\sigma^{2} g\right)=-$
Number of replications


Phenotypic variance $\left(\sigma^{2} p\right)=\sigma^{2} g+$ MSS (error)

\section{Results and Discussion}

Analysis of variance showed significant differences among the genotypes for all the eighteen quantitative parameters, indicating the sufficient genetic variability to be exploited in breeding programme (Table 1).

\section{Genetic variability studies}

\section{Coefficients of variation}

Genetic parameters viz., range, mean, genotypic co-efficient of variation (GCV), phenotypic co-efficient variation (PCV), heritability $\left(\mathrm{h}^{2}\right)$ and genetic advance as per cent of mean (GAM) were calculated to estimate the extent of genetic variability for 18 characters and the results are presented in Table 1.

\section{Plant height at maturity $(\mathrm{cm})$}

Plant height at maturity ranged from $54.66 \mathrm{~cm}$ (Careless) to $70.69 \mathrm{~cm}$ (White Prosperity) with an average mean of 61.15. Low GCV and PCV of 5.38 and 7.88 per cent, was observed for this trait. Low heritability of 46.67 per cent accompanied by low genetic advance over mean was observed 7.58 per cent, among the genotypes.

\section{Number of leaves at maturity}

Number of leaves at maturity ranged from 7.09 (Candyman) to 16.60 (White Prosperity) with an average mean of 11.48. Low GCV and PCV of 20.62 and 27.34 per cent, respectively was observed for this trait. High heritability 56.90 per cent, accompanied with moderate genetic advance over mean 32.05 per cent, was observed among genotypes.

\section{Leaf length at maturity $(\mathrm{cm})$}

Minimum Leaf length at maturity was recorded in careless with $31.53 \mathrm{~cm}$, while the maximum Leaf length recorded in White Prosperity with $54.04 \mathrm{~cm}$ Mean value of 41.44. Moderate GCV and PCV recorded was 41.44 and 13.04 per cent, respectively. The moderate heritability recorded by this trait was 36.41 per cent, whereas high genetic advance over mean was observed 9.78 per cent was observed among the genotypes.

\section{Leaf width at maturity (cm)}

Minimum Leaf width at maturity was recorded in careless with $2.55 \mathrm{~cm}$, while the maximum Leaf width recorded in White Prosperity with $3.63 \mathrm{~cm}$ with mean value of 3.20 . The low GCV and moderate PCV recorded was 5.23 and 9.81 per cent, respectively was recorded. The moderate heritability recorded by this trait was 28.43 per cent, whereas moderate genetic advance over mean was observed to be 5.74 per cent among the genotypes.

\section{Number of days for spike emergence}

Minimum number of days for Spike emergence was recorded as 58.06 in Punjab Beauty while maximum number of days for Spike emergence was recorded 77.40 in $G$. acidanthera with mean value of 63.41. Low GCV and moderate PCV recorded was 6.71 and 8.18 per cent, respectively. The moderate heritability recorded by this trait was 67.19 per cent, whereas moderate genetic advance over mean was observed to be 11.33 per cent, among the genotypes.

\section{Number of days for lowest floret to show colour}

Minimum number of days for lowest floret to show colour was recorded as 67.10 in Punjab Beauty while maximum number of days for 
lowest floret to show colour was recorded as 85.66 in $G$. acidanthera with mean value of 68.90. Low GCV and moderate PCV of 5.99 and 7.34 per cent, was documented, respectively. The moderate heritability recorded by this trait was 66.52 per cent, whereas low genetic advance over mean was observed to be 10.66 per cent among the genotypes.

\section{Number of days for lowest floret to open}

Minimum number of days for lowest floret to open recorded as 69.36 in Punjab Beauty while maximum number of days for lowest floret to open recorded 87.26 in $G$. acidanthera with mean value of 74.037. Low GCV and moderate PCV of 5.22 and 6.65 per cent was recorded respectively. The moderate heritability recorded by this trait was 61.69 per cent, whereas moderate genetic advance over mean was observed to be 8.45 per cent among the genotypes.

\section{Spike length $(\mathrm{cm})$}

Minimum range of Spike length was recorded in G. acidanthera with $58.33 \mathrm{~cm}$, while maximum range length of Spike was recorded $130.00 \mathrm{~cm}$ in White Prosperity with mean value of 78.099. Low GCV and moderate PCV of 17.74 and 18.62 per cent was recorded respectively. The moderate heritability recorded by this trait was 90.71 per cent, whereas low genetic advance over mean was observed to be 34.80 per cent among the genotypes.

\section{Rachis length (cm)}

The minimum range of Rachis length was recorded in $G$. acidanthera with $25.41 \mathrm{~cm}$, while the maximum range of Rachis length was recorded $59.00 \mathrm{~cm}$ in White Prosperity with mean value of 32.742 . The moderate GCV and high PCV of 20.20 and 22.42 per cent was documented respectively. The moderate heritability recorded by this trait was 81.18 per cent, whereas high genetic advance over mean was observed to be 37.50 per cent among the genotypes.

\section{Spike girth $(\mathrm{cm})$}

The minimum range of Spike girth was recorded in $G$. acidanthera with $5.56 \mathrm{~cm}$, while maximum range of Spike girth recorded was $12.55 \mathrm{~cm}$ in White Prosperity with mean value of 8.24. The moderate GCV and high PCV was found to be 17.36 and 21.45 percent, respectively. The moderate heritability recorded by this trait was 65.52 per cent, whereas high genetic advance over mean was observed as 28.95 per cent among the genotypes.

\section{Number of florets}

Minimum Number of florets was recorded in G. acidanthera with 16.66 while maximum number of florets was recorded 7.00 in White Prosperity with mean value of 11.53 . It was found that was high GCV and PCV of 30.62 and 37.23 per cent, respectively. The high heritability recorded by this trait was 67.63 per cent, whereas high genetic advance over mean was observed to be 51.87 per cent, among the genotypes.

\section{Number of open florets}

Minimum Number of open florets was recorded in G. acidanthera with 14.00 while maximum Number of open florets was recorded 6.00 in White Prosperity with mean value of 9.79. It was found that was high GCV and PCV of 21.44 and 26.42 per cent, respectively. The high heritability recorded by this trait was 65.84 per cent, whereas high genetic advance over mean was observed to be 35.84 per cent, among the genotypes. 


\section{Days to $50 \%$ of flowering}

Minimum Days to $50 \%$ of flowering was recorded in $G$. acidanthera with 5.00 days while maximum Days to $50 \%$ of flowering was recorded 7.66 days in White Prosperity with mean value of 4.60. It was found that was high GCV and PCV of 17.39 and 32.04 per cent, respectively. The high heritability recorded by this trait was 29.46 per cent, whereas high genetic advance over mean was observed to be 19.44 per cent, among the genotypes.

\section{Number of corms produced}

Minimum number of corms produced in Red Beauty with 1.33 while maximum number of corms produced was recorded 4.00 in Arka Amar with mean value of 2.38. It was found that was high GCV and PCV of 17.27 and 37.48 per cent, respectively. The high heritability recorded by this trait was 21.25 per cent, whereas high genetic advance over mean was observed to be 16.40 per cent, among the genotypes.

\section{Weight of corms (g)}

Minimum weight of corms ( $\mathrm{g}$ ) was recorded in Red Beauty with $36.66 \mathrm{~g}$ while maximum weight of corms (g) was recorded $74.33 \mathrm{~g}$ in Arka Amar with mean value of 52.53. It was found that was high GCV and PCV of 12.98 and 22.58 per cent, respectively. The high heritability recorded by this trait was 33.06 per cent, whereas high genetic advance over mean was observed to be15.37 per cent, among the genotypes.

\section{Number of cormels produced}

Minimum number of cormels produced in Red Beauty with 10.33 while maximum number of cormels produced was recorded 48.00 in Arka Amar with mean value of 18.93 . It was found that was moderate GCV and PCV of 42.91 and 249.89 per cent, respectively. The high heritability recorded by this trait was 73.95 per cent, whereas high genetic advance over mean was observed 76.01 per cent, among the genotypes.

\section{Weight of cormels (g)}

Minimum weight of cormels (g) was recorded in Red Beauty with $3.10 \mathrm{~g}$ while maximum Weight of cormels $(\mathrm{g})$ was recorded $40.66 \mathrm{~g}$ in Arka Amar with mean value of 9.49 per cent. It was found that was moderate GCV and PCV of 91.98 and 96.02 per cent, respectively. The high heritability recorded by this trait was 91.75 per cent, whereas high genetic advance over mean was observed to be 181.49 per cent, among the genotypes.

\section{Spike per plant}

Minimum Spike per plant was recorded in $G$. acidanthera with 1.067 while maximum Spike per plant was recorded 2.53 in Arka Amar with mean value of 1.629 per cent. It was found that was moderate GCV and PCV of 18.63 and 27.74 per cent, respectively. The high heritability recorded by this trait was 43.60 per cent, whereas high genetic advance over mean was observed to be 25.77 per cent, among the genotypes.

\section{Genetic variability studies}

\section{Coefficients of variation}

The phenotypic variance measures the magnitude of variation arising out of differences in phenotypic values while, the genotypic variance measures the magnitude of variation arising out differences in genotypic values. The phenotypic and genotypic variance in absolute values cannot be used to compare magnitude of variability of different growth and yield parameters. 
Table.1 Estimates of phenotypic and genotypic coefficients of variation, heritability and genetic advance for difference traits of gladiolus genotypes

\begin{tabular}{|c|c|c|c|c|c|c|c|c|}
\hline Sl. No. & Characters & Range & & Mean & GCV \% & PCV \% & $\mathrm{h}^{2} \mathrm{BS} \%$ & GAM \\
\hline 1 & Plant height at maturity & 54.66 & 70.69 & 61.15 & 5.38 & 7.88 & 46.67 & 7.58 \\
\hline 2 & Number of leaves at maturity & 7.093 & 16.60 & 11.48 & 20.62 & 27.34 & 56.90 & 32.05 \\
\hline 3 & Leaf length at maturity & 31.53 & 51.04 & 41.44 & 7.86 & 13.04 & 36.41 & 9.78 \\
\hline 4 & Leaf width at maturity & 2.55 & 3.63 & 3.20 & 5.23 & 9.81 & 28.43 & 5.74 \\
\hline 5 & Number of days for Spike emergence & 58.06 & 77.40 & 63.41 & 6.71 & 8.18 & 67.19 & 11.33 \\
\hline 6 & Number of days for lowest floret to show colour & 67.10 & 85.66 & 68.90 & 5.99 & 7.34 & 66.52 & 10.66 \\
\hline 7 & Number of days for lowest floret to open & 69.36 & 87.26 & 74.03 & 5.22 & 6.65 & 61.69 & 8.45 \\
\hline 8 & Spike length & 58.33 & 130.00 & 78.09 & 17.74 & 18.62 & 90.71 & 34.80 \\
\hline 9 & Rachis length & 25.41 & 59.00 & 32.74 & 20.20 & 22.42 & 81.18 & 37.50 \\
\hline 10 & Spike girth & 5.56 & 12.55 & 8.24 & 17.36 & 21.45 & 65.52 & 28.95 \\
\hline 11 & Number of florets & 16.66 & 7.00 & 11.53 & 30.62 & 37.23 & 67.63 & 51.87 \\
\hline 12 & Number of open florets & 14.00 & 6.00 & 9.79 & 21.44 & 26.42 & 65.84 & 35.84 \\
\hline 13 & Days to $50 \%$ of flowering & 5.00 & 7.66 & 4.60 & 17.39 & 32.04 & 29.46 & 19.44 \\
\hline 14 & Number of corms produced & 1.33 & 4.00 & 2.38 & 17.27 & 37.48 & 21.25 & 16.40 \\
\hline 15 & Weight of corms (g) & 36.66 & 74.33 & 52.53 & 12.98 & 22.58 & 33.06 & 15.37 \\
\hline 16 & Number of cormels produced(g) & 10.33 & 48.00 & 18.93 & 42.91 & 49.89 & 73.95 & 76.01 \\
\hline 17 & Weight of cormels & 3.10 & 40.66 & 9.49 & 91.98 & 96.02 & 91.75 & 181.49 \\
\hline 18 & Spike per plant & 1.067 & 2.53 & 1.62 & 18.63 & 27.74 & 43.60 & 25.77 \\
\hline
\end{tabular}

GCV- Genotypic co-efficient of variance

PCV- Phenotypic co-efficient of variance

$\mathrm{h}_{\mathrm{BS}}^{2}$ - Broad sense heritability

GAM- Genetic advance as per cent of mean 
Hence, these parameters are converted into co-efficient of variance at genotypic and phenotypic levels.

The estimates of phenotypic and genotypic coefficients of variation gave a clear picture of amount of variations present in the available varieties. For all the characters studied, phenotypic coefficients of variation were higher in magnitude than genotypic coefficients of variation, though difference was very less in majority of the case. Thus, it could be reduced that these traits were less influenced by environmental factors. Coefficient of variation varied in magnitude from character to character (either low or moderate or high). The higher magnitude of genetic coefficient of variation, showing narrow difference between PVAR and GVAR. Simple is selection procedure. This would be sufficient to improve desirable traits in gladiolus.

The phenotypic coefficients of variation (PVAR) was found high in weight of cormels, spike length, number of corms produced, number of florets, days to $50 \%$ of flowering, number of leaves at maturity, number of open florets and weight of corms. Whereas, moderate PVAR was found for Leaf length at maturity, leaf width at maturity, number of days for spike emergence, number of primary branches, days to 50 per cent flowers, number of leaves, number of days for lowest floret to show colour and number of days for lowest floret to open. Similar results for phenotypic coefficients of variation were observed by Kumar and Yadav (2005) and Ram et al., (2005) and Saini et al., (1991).

Genotypic coefficients of variation (GVAR) was found high for weight of cormels, number of cormels produced, number of florets, days to flowering, number of leaves at maturity, rachis length, whereas moderate GVAR was observed for spike length, days to
$50 \%$ of flowering, spike girth, number of corms produced, weight of corms, number of leaves, GVAR was recorded low for leaf width at maturity. Similar results for genotypic coefficients of variation were observed by by Kumar and Yadav (2005) Ram et al., (2005) and Saini et al., (1991).

\section{Heritability}

The genotypic coefficient of variation does not offer full scope to estimate the variations that are heritable and therefore, estimation of heritability becomes necessary. Burton and De Vane (1953) had suggested that genetic coefficient of variation along with heritability estimates would give a reliable indication of expected amount of improvement through selection.

The estimates of heritability (broad sense) varied from 21.25- $91.75 \%$ for different characters under the study. It was found high for all the traits viz., weight of cormels, spike length, rachis length, number of cormels produced, number of florets, number of days for spike emergence, spike girth, number of days for lowest floret to show colour, number of open florets, number of days for lowest floret to open, number of leaves at maturity, plant height at maturity, weight of corms whereas, medium heritability was observed for number of corms produced (Kumar and Yadav, 2005; Ram et al., 2005 and Saini et al., 1991).

High heritability estimates coupled with high genetic advance over mean was observed for test weight, yield per plant, days to flowering, days to flower bud initiation, leaf area, plant height, leaf area index, number of secondary branches, number of flowers per plant, flower size, plant spread, number of primary branches, days to 50 per cent flowering and number of leaves and the moderate genetic advance were recorded for dry matter and 
duration of flowering. Similar results were also observed by Singh and Sen (2000), Nandakishore and Raghava (2001) and Pal and George (2002).

\section{Acknowledgement}

The University of Agricultural Sciences, Raichur (College of Agriculture, Raichur) is gratefully acknowledged for providing research facilities.

\section{References}

Burton, G. W. and Devane, E. M., 1953, Estimating heritability in tall fescue (Festuca arundinacea) from replicated clonal material. Agro. J., 45: 478-481.

Hanson, G. H., Robinson, H. F. and Comstock, R. E., 1956, Biometrical studies of yield in segregating population of Korean Lespedeza. Agron. J., 48: 267-282.

Johnson, H. W., Robinson, H. F. and Constock, R. E., 1955, Estimates of genetic and environmental variability in soybean. Agron. J., 47: 314-319.

Kumar, P., Dubey, R.K., Singh, R.S. and Ramesh Kumar., 2007. Effect of Trichoderma viridae and Pseudomonas fluorescence on corm and cormel production in gladiolus. J.Orn Hort., 10(3): 184186.

Nandakishore and Raghava, S. P. S., 2001, Variability studies in African marigold. J. Orn. Hort., (New Series), 4 (2): 124125.

Pal, P. and George, S. V., 2002, Genetic variability and correlation studies in chrysanthemum. Hort. J., 15 (2): 75-81.

Ram, R.B, Tomar, K.S and Datta, S.K., 2005. Performance of certain gladiolus varieties under sodic conditions. $J$. Orna. Hort., 8(1): 77-78.

Saini, R.S., Gupta, A.K. and Yamadagni, R.V., 1991. Performance of different cultivars of gladiolus (Gladiolus grandifloras L.) under Hissar conditions. South Indian Hortic., 39: 99-101.

Singh, D. and Sen, N. L., 2000, Genetic variability, heritability and genetic advance in marigold. J. Orn. Hort., (New series), 36 (2): 75-78.

Sivasubramanian, V. and Menon, M. P., 1973, Path analysis for yield and yield components of rice. Madras Agril. J., 60: 1217-1221.

Vavilov, N. I., 1951, The origin, variation, immunity and breeding of cultivated plants. Chronica Bot., 13: 366 p.

Wright, S., 1921, Correlation and causation. J. Agri. Res., 20: 557-585.

\section{How to cite this article:}

Ishwarraddy, K. Kandpal, A. Hugar, G. Ramesh and Amaregouda, A. 2018. Genetic Variability Studies in Gladiolus (Gladiolus grandiflora L.). Int.J.Curr.Microbiol.App.Sci. 7(11): 25662573. doi: https://doi.org/10.20546/ijcmas.2018.711.292 